\title{
Genotypic Variation of Microelements Concentration in Sesame (Sesamum indicum L.) Mini Core Collection
}

\author{
Sarita K. Pandey ${ }^{1,2} \cdot$ Eshita Majumder $^{1}$ Tapash Dasgupta ${ }^{1}$
}

Received: 25 April 2016/ Accepted: 13 February 2017/Published online: 4 March 2017

(C) NAAS (National Academy of Agricultural Sciences) 2017

\begin{abstract}
Evaluation of germplasm for mineral content and selecting varieties with high quantities of essential minerals and incorporating those varieties in breeding program can assist in developing mineral-efficient crops with higher yield which can accumulate minerals from marginal soil. Sesame an oldest oilseed crop is a popular food with medicinal value although its production is often focussed in marginal and sub-marginal lands. In the present study, 60 sesame genotypes of diverse origin collected from Bangladesh, Bulgaria, India and USA were examined in the acid-digested samples by atomic absorption spectrophotometer for $\mathrm{Fe}, \mathrm{Zn}, \mathrm{Cu}, \mathrm{Mn}, \mathrm{Cr}$ and $\mathrm{Co}$ contents. All elements except $\mathrm{Cr}$ were found to be highly variable among genotypes. A significant discrimination showed that elements content in the sesame seeds was a seed coat coloured specific character. High-yielding developed varieties of India contain high $\mathrm{Zn}$ but low Fe concentration in seed. The concentration of mineral elements in black-seeded genotypes was significantly higher than those in white seeded. The indigenous collections were found to be a good reservoir of mineral elements. Correlation study among trace elements and yield attributes indicated that though $\mathrm{Fe}$ and $\mathrm{Zn}$ were not correlated significantly with yield and its components, but the two elements were interrelated. Phenotypic and genotypic coefficient of variability and heritability were high for $\mathrm{Fe}$ and $\mathrm{Zn}$. The study suggests that observed large genetic variability for element concentrations in the genotypes provides good prospects to breed improved sesame cultivars with elevated levels of micronutrients to mitigate mineral deficiency.
\end{abstract}

Keywords Correlation $\cdot$ Genetic variability $\cdot$ Micronutrients $\cdot$ Seed colour $\cdot$ Sesame

\section{Introduction}

Micronutrient malnutrition is currently of alarming proportions in many developing nations including India and hence becoming a growing concern in the world [24]. The research interest has been centred to micronutrient malnutrition over

Electronic supplementary material The online version of this article (doi:10.1007/s40003-017-0252-z) contains supplementary material, which is available to authorized users.

Sarita K. Pandey

isarita06@gmail.com

1 Department of Genetics and Plant Breeding, University of Calcutta, Kolkata, India

2 International Crops Research Institute for Semi-Arid Tropics, Patancheru, Telangana, India the last few years because it leads to several diseases and causes large economic costs to society [23]. The World Health Organization (WHO) has estimated that nearly 3.7 billion people were iron-deficient, whereas in India anaemia prevalence among young children remains over $70 \%$ in most of the parts [10]. All the studied elements in the present study namely $\mathrm{Fe}, \mathrm{Zn}, \mathrm{Cu}$ and $\mathrm{Mn}, \mathrm{Cr}$ and $\mathrm{Co}$ functions as an essential cofactor present in certain enzymes and are crucial in numerous biochemical pathways [20]. Major reason for the widespread occurrence of micronutrient deficiencies in human beings is the high consumption of foods with very low content of micronutrients. Earlier breeding program were mostly focused on the improvement of physiochemical and morphological characteristics of grain [8]. To mitigate the problem of micronutrient malnutrition, several ways have been adopted such as pharmaceutical supplementation, dietary diversification and industrial fortification, but it has 
not been fully utilized in the developing countries because of poor infrastructure and delivery system [9]. Bio-fortification of crops especially for mineral nutrients is a sustainable and economical approach and provides long-term solution and has great potential for improving the mineral nutritional status and health of poor populations of the developing world [9]. In major cereals, a number of genotypes with enhanced concentrations of elements have been developed to improve the nutritional quality of grain for human consumption, but no such major progress has been reported in oilseed crops especially in sesame [6], and hence, exploitation of large genetic variation for microelement in existing germplasm is, therefore, a high-priority research area to minimize the extent of their deficiencies. Sesame (Sesamum indicum L.) is an oldest oilseed with high protein (10-25\%) and oil content (34-63\%) [16]. Sesame seed is rich in vitamins, minerals and lignans, and it is a popular food with medicinal value [7]. In India, sesame is generally cultivated for oil $(65 \%)$ and food (35\%), and hence, it is one of the major sources of dietary energy and mineral micronutrients. Improvement of cerealbased foods by adding whole oil seeds has received significant consideration [1]. According to a study of Alobo [3], around $40 \%$ of millet flour has been replaced by defatted whole sesame seeds for biscuits preparation because of its high nutritious value. In this study, concentration of six essential microelements, $\mathrm{Fe}, \mathrm{Zn} \mathrm{Cu}, \mathrm{Mn}, \mathrm{Cr}$, and $\mathrm{Co}$ was estimated in the sesame seeds of diverse genotypes including landraces, mutant lines, high-yielding developed varieties, indigenous collections (IC) and exotic collections (EC) from India, Bangladesh, USA and Bulgaria. An understanding of the nature of genetic variability will have a direct effect on developing efficient breeding strategies for micronutrient content.

\section{Materials and Methods}

The mini core subset comprising only about $10 \%$ of the core collection (611 accessions from USA, Bulgaria, India and Bangladesh) drawn from NBPGR, New Delhi, held at Department of Genetics and Plant Breeding, Calcutta University, was selected for the present study. The present mini core collection still signifies the diversity of the entire core collection, and genotypes for mini core collection were selected based on origin and geographical distribution, agronomical, morphological and quality traits. Core collections ( $10 \%$ of total collection) and mini core collections (either $10 \%$ of core collection or $1 \%$ of total collection) are of great value due to its drastically reduced size for proper exploitation of genetic resources [21]. Sixty sesame genotypes (Supplementary Table 1) were grown in randomized block design with three replications at agricultural experimental station of Calcutta University at Baruipur $\left(22.35^{\circ} \mathrm{N}\right.$, $88.44^{\circ} \mathrm{E}$.). The crop was grown following normal cultural practice in Rabi/summer season in 2011, 2012 and 2013. Five randomly selected plants from each replication were recorded for morphological trait namely days to $50 \%$ flowering (DTF), days to maturity (DTM), capsule length (CL), number of capsules/plant (NCP), number of seeds/capsule (NSC), 1000 seed weight (SW) and seed yield/plant (SY). Mean of three successive seasons was used to construct the table of morphological characters.

\section{Estimation of Trace Elements}

\section{Digestion Procedures}

For wet digestion, three replicates of $1 \mathrm{~g}( \pm 0.0001 \mathrm{~g})$ from crushed and homogenized samples for each year were treated with $10 \mathrm{~mL}$ mixture of three acids of $70 \% \mathrm{HNO}_{3}$, $70 \% \mathrm{HClO}_{4}$ and $98 \% \mathrm{H}_{2} \mathrm{SO}_{4}(10: 4: 1)$ at $80^{\circ} \mathrm{C}$ on the hot plate. The sample was heated electrically to nitrify and decompose the sesame seeds until the solution became clear and dry. After cooling, the residue was diluted with deionized water and then filtered. Then, the volume was made up to $100 \mathrm{~mL}$ with distilled water. The blank digestions were also carried out in the same way.

\section{Calibration Curves}

The calibration curves were prepared from standards by dissolving appropriate amounts of the metal salts (SigmaAldrich, USA) in purified nitric acid, diluting with deionised water and storing as stock solutions in a quartz flask. Fresh working solutions of final concentration of 2,1 and $0.5 \mathrm{ppm}$ were obtained by serial dilution of stock solutions. The respective standards that were to be analysed in a BeerLambert analysis concentrations were entered and the units were assigned $(\mathrm{mg} / \mathrm{L}=\mathrm{ppm})$. The standard certified reference materials for $\mathrm{Fe}, \mathrm{Zn} \mathrm{Cu}, \mathrm{Mn}, \mathrm{Cr}$ and $\mathrm{Co}$ were all 1000 $\mathrm{mgL}^{-1}$ provided from the Export Quality Laboratory, BCKV, West Bengal. The measurements were taken by calibration using aqueous mixed standards prepared in $\mathrm{HNO}_{3}(1 \mathrm{M})$. All calibration curves were based on five standard stock solutions $\left(1 \mathrm{gL}^{-1}\right)$ including a blank. For preparation of aqueous standard solutions, appropriate dilutions of a $1 \mathrm{gL}^{-1}$ multi-element solution were applied. The calibration ranges were selected according to the expected concentrations of the elements of interest and depended on the technique applied.

\section{Sample Analysis}

The concentrations of elements were determined in an airacetylene flame by AAS method using deuterium background correction. Varian AA240 atomic absorption 
spectrometers were used for metal analyses. Measurements were taken using a hollow cathode lamp for $\mathrm{Fe}, \mathrm{Cu}, \mathrm{Zn}$, $\mathrm{Mn}, \mathrm{Cr}$ and $\mathrm{Co}$ at wavelengths of 248.3, 324.8, 213.9, 279.5, 357.9 and $240.7 \mathrm{~nm}$, respectively. The measurement was replicated five times to minimize the error for each replicate. Sixty genotypes under study were estimated for mineral element content, and the table of mineral element content was developed on the basis of mean data.

\section{Data Analysis}

The data analysis was conducted by using a SPSS (version17.0; Chicago, IL, USA) [17]. An initial descriptive statistics, including mean, standard deviation (SD), standard error (SE), critical difference (CD) range and frequencies, was performed. Correlation analysis was used to find the relationship between microelements and yield attributing traits. Analysis of variance was also computed for all the thirteen traits using SPSS. Genetic parameters were estimated for the 13 characters to identify variability among 60 genotypes. Genotypic $\left(\sigma^{2} \mathrm{G}\right)$, phenotypic $\left(\sigma^{2} \mathrm{P}\right)$ and error $\left(\sigma^{2} \mathrm{E}\right)$ variances were calculated for each trait.
Phenotypic (PCV) and genotypic coefficients of variation (GCV) were also calculated [5]. Broad-sense heritability was defined as the ratio of the genetic variance $\left[\sigma^{2} \mathrm{G}\right]$ between genotypes to the total phenotypic variance $\left(\sigma^{2}\right.$ $\mathrm{P}=\sigma^{2} \mathrm{G}+\sigma^{2} \mathrm{E}$ ) [2]. Genetic advance was calculated as GA $(\%)=K \times \sigma_{\mathrm{P}} \times h_{\mathrm{bs}} \times 100$, where $\mathrm{K}$ (selection differential at $5 \%)=2.06$ where, $\sigma_{\mathrm{P}}=$ the phenotypic standard deviation and $h_{\mathrm{bs}}=$ broad-sense heritability. Genetic advance over mean as \% (GAM) was calculated as per cent of the genetic advance over the mean.

\section{Results and Discussion}

\section{Variation of Mineral Concentration and Morphological Traits in 60 Genotypes}

The analysis of variance revealed significant variation among genotypes for all traits (Table 1). Fe content varied from 35.20 (Savitri) to 231.50 (EC-90) ppm among the 60 genotypes (Table 2). The genotype EC-107 possessed maximum $\mathrm{Zn}$ concentration (80.09 ppm), minimum being

Table 1 Analysis of variance table for thirteen characters of 60 sesame genotypes

\begin{tabular}{lrrrrrrrrrrrrrr}
\hline $\begin{array}{l}\text { Source of } \\
\text { Variance }\end{array}$ & $d f$ & $\mathrm{Fe}(\mathrm{ppm})$ & $\begin{array}{l}\mathrm{Zn} \\
(\mathrm{ppm})\end{array}$ & $\begin{array}{l}\mathrm{Cu} \\
(\mathrm{ppm})\end{array}$ & $\begin{array}{l}\mathrm{Mn} \\
(\mathrm{ppm})\end{array}$ & $\begin{array}{l}\mathrm{Co} \\
(\mathrm{ppm})\end{array}$ & $\begin{array}{l}\mathrm{Cr} \\
(\mathrm{ppm})\end{array}$ & DTF & DTM & $\begin{array}{l}\mathrm{CL} \\
(\mathrm{cm})\end{array}$ & NCP & NSC & $\begin{array}{l}\text { SW } \\
(\mathrm{g})\end{array}$ & $\begin{array}{l}\text { SY }(\mathrm{g}) \\
\text { Replication }\end{array}$ \\
\hline Treatment & 2 & 1.896 & 0.052 & 0.27 & 0.166 & 0.177 & 0.007 & 0.272 & 0.23 & 0.133 & 0.067 & 0.110 & 0.072 & 0.15 \\
Error & 118 & 1.754 & 0.013 & 0.033 & 0.020 & 0.059 & 0.006 & 0.973 & 1.01 & 0.009 & 0.009 & 0.009 & 0.006 & 0.015 \\
\hline
\end{tabular}

** Significant at $1 \%$ level of significance; * significant at $5 \%$ level of significance; days to $50 \%$ flowering (DTF), days to maturity (DTM), capsule length (CL), number of capsules/plant (NCP), number of seeds/capsule (NSC), 1000 seed weight (SW) and seed yield/plant (SY)

Table 2 Mean, critical difference and standard error and genetic parameters of 13 characters of sesame

\begin{tabular}{|c|c|c|c|c|c|c|c|c|c|c|c|c|c|}
\hline & $\mathrm{Fe}(\mathrm{ppm})$ & $\mathrm{Zn}(\mathrm{ppm})$ & $\mathrm{Cu}(\mathrm{ppm})$ & $\mathrm{Mn}(\mathrm{ppm})$ & Co (ppm) & $\mathrm{Cr}(\mathrm{ppm})$ & DTF & DTM & $\mathrm{CL}(\mathrm{cm})$ & $\mathrm{NCP}$ & NSC & SW (g) & $S Y(g)$ \\
\hline Mean & 105.7 & 61.79 & 19.46 & 22.98 & 35.92 & 0.63 & 32.78 & 89.69 & 2.16 & 56.47 & 55.5 & 3.12 & 10.07 \\
\hline SD & 47.29 & 8.48 & 2.23 & 4.13 & 10.57 & 1.55 & 4.49 & 2.53 & 0.22 & 11.97 & 6.27 & 0.43 & 2.24 \\
\hline Max & 231.5 & 80.09 & 25.2 & 35.9 & 53.3 & 2.1 & 48 & 95 & 2.8 & 99.89 & 72.49 & 4.32 & 18.01 \\
\hline Min & 35.2 & 43.09 & 12.2 & 14.6 & 9.3 & 0.1 & 27 & 85 & 1.59 & 30.14 & 43.66 & 2.2 & 6.57 \\
\hline CD (1\%) & 2.87 & 0.24 & 0.39 & 0.3 & 0.52 & 0.17 & 2.14 & 2.19 & 0.2 & 0.2 & 0.2 & 0.17 & 0.26 \\
\hline $\mathrm{CD}(5 \%)$ & 2.16 & 0.18 & 0.29 & 0.23 & 0.39 & 0.12 & 1.61 & 1.64 & 0.15 & 0.15 & 0.15 & 0.13 & 0.2 \\
\hline SE & 0.76 & 0.06 & 0.1 & 0.08 & 0.14 & 0.04 & 0.56 & 0.58 & 0.05 & 0.05 & 0.05 & 0.04 & 0.07 \\
\hline $\mathrm{CV}$ & 1.25 & 0.18 & 0.93 & 0.61 & 0.67 & 1.24 & 3 & 1.12 & 4.42 & 0.165 & 0.17 & 2.54 & 1.21 \\
\hline $\mathrm{Vg}$ & 221.8 & 72.18 & 4.99 & 17.17 & 112.6 & 5.36 & 19.01 & 5.14 & 0.04 & 143.3 & 39.34 & 0.18 & 5.03 \\
\hline $\mathrm{Vp}$ & 221.9 & 72.19 & 5.02 & 17.19 & 112.7 & 5.37 & 19.99 & 6.15 & 0.05 & 143.31 & 39.35 & 0.19 & 5.04 \\
\hline PCV & 44.57 & 13.75 & 11.51 & 18.04 & 29.55 & 24.56 & 13.64 & 2.76 & 10.99 & 21.2 & 11.29 & 14.03 & 22.31 \\
\hline GCV & 44.55 & 13.75 & 11.47 & 18.03 & 29.54 & 24.52 & 13.3 & 2.52 & 10 & 21.2 & 11.29 & 13.8 & 22.28 \\
\hline $\mathrm{H}^{2}$ & 99.9 & 99.9 & 99.3 & 99.9 & 99.9 & 99.7 & 95.1 & 83.5 & 83.8 & 99.9 & 99.9 & 96.7 & 99.7 \\
\hline GAM & 28.73 & 28.28 & 23.32 & 36.72 & 60.21 & 44.8 & 26.5 & 4.72 & 18.7 & 43.22 & 23.01 & 27.8 & 45.66 \\
\hline
\end{tabular}

Days to 50\% flowering (DTF), days to maturity (DTM), capsule length (CL), number of capsules/plant (NCP), number of seeds/capsule (NSC), 1000 seed weight (SW) and seed yield/plant (SY). Coefficient of variation (CV), phenotypic coefficient of variation (PCV), genotypic coefficient of variation $(\mathrm{GCV})$, genetic and phenotypic variances $(\mathrm{Vg}$ and $\mathrm{Vp})$, genetic advance over mean $(\mathrm{GAM})$, broad-sense heritability $\left(\mathrm{H}^{2}\right)$ 
Fig. 1 Distribution and differences for contents of $\mathrm{Fe}$, $\mathrm{Zn}, \mathrm{Cu}, \mathrm{Mn}$, Co and $\mathrm{Cr}$ among 60 sesame genotypes
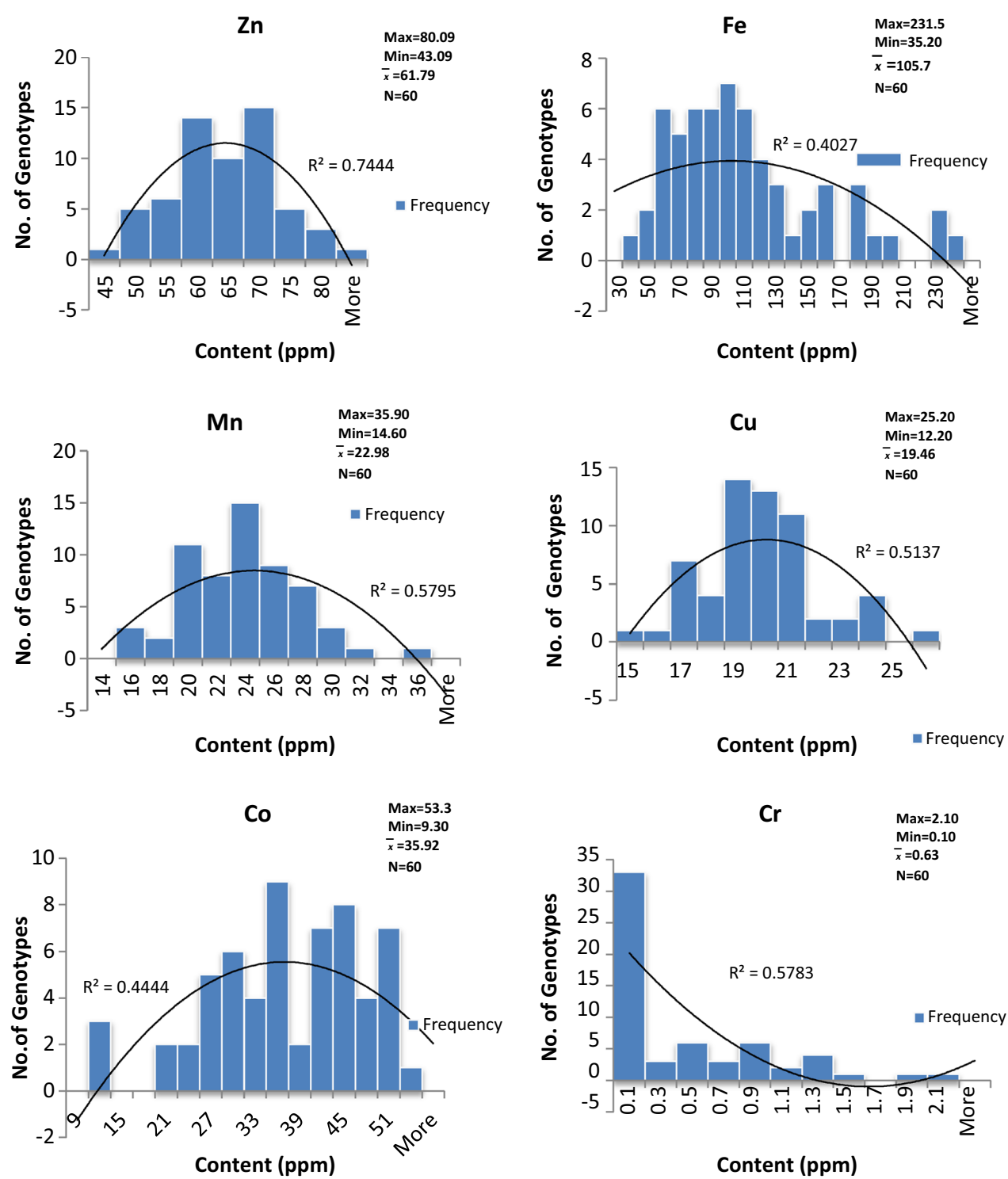

shown by the indigenous collection IC-60 (43.09). Özcan et al. [14] and Cao et al. [6] have reported the similar range of microelements in sesame collection of Turkey and China, respectively. Quite a high range of variation of $\mathrm{Fe}$ and $\mathrm{Zn}$ content existed among the genotypes (Fig. 1). High range of variation was also observed for $\mathrm{Cu}, \mathrm{Mn}, \mathrm{Co}$ and $\mathrm{Cr}$ content of the genotypes. The mineral content varied from 12.20 (IC-60) to 25.20 (DSS-09) ppm for $\mathrm{Cu}, 14.6$ (EC-79) to 35.9 (EC-90) ppm for Mn, 9.3 (EC-79) to 53.3 (TMV-6) ppm for Co, 0.1 (TKG-22) to 2.10 (EC-107) ppm for $\mathrm{Cr}$ (Table 2). A significant range of variation was observed for all the traits (Table 2), and this variation provided chances to select materials with high contents of microelements. Obiajunwa et al. [13] reported sesame seeds as a good reservoir of essential and beneficial micronutrients such as $\mathrm{Cr}, \mathrm{Mn}, \mathrm{Fe}, \mathrm{Ni}, \mathrm{Cu}$ and $\mathrm{Zn}$. Maximum yield was obtained from IC-63 followed by IC-59 and IC-62. Phenotypic variances and phenotypic coefficients of variation exhibited a bit higher values but maintained a close relation with genotypic variances and genotypic coefficients of variation for all the traits, indicating low $\mathrm{G} \times \mathrm{E}$ interaction. The phenotypic coefficient of variation (PCV) and genotypic coefficient of variation (GCV) were high for $\mathrm{Fe}$ content (44.57; 44.55\%) followed by Co content $(29.55,29.54 \%)$ and $\mathrm{Cr}$ content $(24.56 ; 24.52 \%)$ of the seeds (Table 2); however, low GCV and PCV were observed for days to maturity $(2.52 ; 2.76 \%)$, followed by capsule length $(10.06$; $10.99 \%)$ and number of seeds per capsules $(11.29 ; 11.29 \%)$ (Table 2). High estimates for these genetic parameters were also reported by Sarwar et al. [19]. High heritability was recorded for all of the thirteen traits. A moderate genetic advance (GA\%) over mean was found among 
Table 3 Comparison of mineral content among different collection of sesame genotypes

\begin{tabular}{|c|c|c|c|c|c|c|}
\hline Collections & $\mathrm{Fe}$ & $\mathrm{Zn}$ & $\mathrm{Cu}$ & $\mathrm{Mn}$ & $\mathrm{Co}$ & $\mathrm{Cr}$ \\
\hline \multicolumn{7}{|c|}{ Developed varieties } \\
\hline Mean & 83.73 & 61.68 & 19.6 & 22.6 & 45.3 & 0.4 \\
\hline Standard error & 5.99 & 1.84 & 0.5 & 0.85 & 0.90 & 0.07 \\
\hline Range & 116.3 & 30.52 & 9.5 & 14.4 & 17.8 & 1.09 \\
\hline \multicolumn{7}{|l|}{ Exotic collection } \\
\hline Mean & 119.76 & 61.28 & 19.0 & 22.8 & 27.4 & 0.6 \\
\hline Standard error & 9.88 & 1.31 & 0.3 & 0.95 & 1.68 & 0.1 \\
\hline Range & 174.5 & 28.89 & 7.4 & 21.3 & 29.8 & 2 \\
\hline \multicolumn{7}{|c|}{ Indigenous collection } \\
\hline Mean & 124.43 & 62.39 & 18.0 & 23.6 & 32.2 & 0.1 \\
\hline Standard error & 17.67 & 3.34 & 0.8 & 1.03 & 2.37 & 0.0 \\
\hline Range & 184.5 & 33.84 & 10.9 & 12.6 & 24 & 0.3 \\
\hline
\end{tabular}

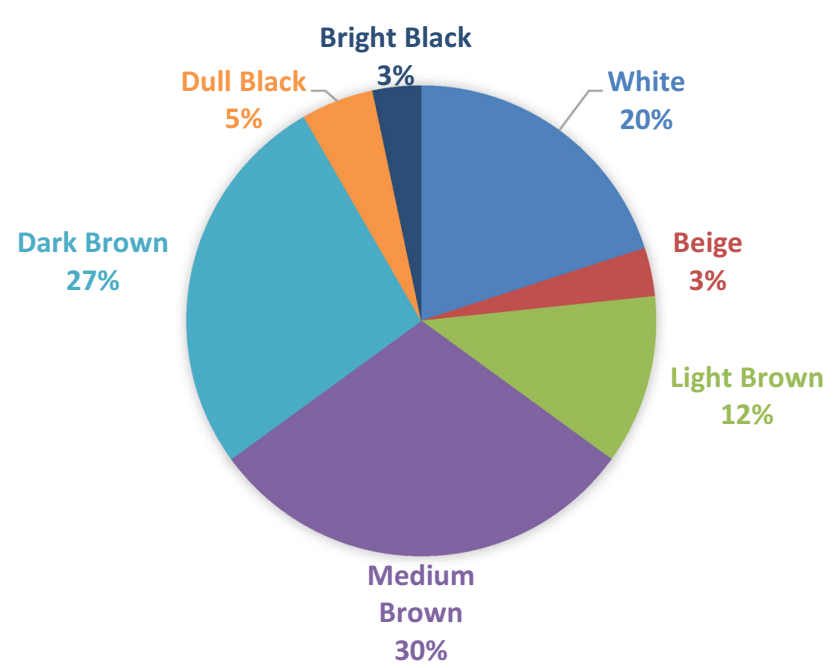

Fig. 2 Percentage of different colour genotypes in mini core collection of sesame

genotypes for $\mathrm{Fe}, \mathrm{Mn}, \mathrm{Zn}, \mathrm{Cu}$, days to $50 \%$ flowering, days to maturity, capsule length, number of seeds/capsule and 1000 seed weight, whereas for number of capsules/plant and seed yield/plant, $\mathrm{Cr}$ and Co content a high GA\% (more than $40 \%$ ) over mean was estimated (Table 2).

\section{Difference of Mineral Concentration Between Indigenous, Exotic Collection and Developed Varieties}

Among different groups of genotypes, high iron content was found in indigenous collections (124.4 ppm); low content was observed in high-yielding varieties (83.73 ppm) of India. Similarly, Zn content was also high in indigenous collection $(62.39 \mathrm{ppm})$ and low in exotic collections (61.28 ppm) (Table 3; Fig. 2). High Fe content with moderate $\mathrm{Zn}$ content in the seeds of sesame was earlier reported by Alyemeni et al [4], and they suggested that incorporation of sesame seeds in bakery industry at appropriate levels may fulfil the recommended daily dietary allowances of minerals. High Cu content (19.65 ppm) was found in high-yielding varieties of India, followed by exotic collections (19.42 ppm), while lowest was observed in indigenous collections (18.84 ppm). High $\mathrm{Cr}$ content was estimated in exotic collections $(0.65 \mathrm{ppm})$, minimum being in indigenous collections (0.17 ppm). High-yielding varieties of India contained high Co content (45.30 ppm), while in exotic collections low Co content was recorded (27.43 ppm) (Table 3). On the contrary, Mn content was found to be high in indigenous collections (23.62 ppm), low content being in high-yielding varieties $(22.71 \mathrm{ppm})$. Thus, high-yielding varieties of sesame need to be upgraded genetically to become more nutritious. Based on average mean value of different collections belonging to Indian and exotic, the trend line depicted that indigenous collections were found to be good source of microelements (Table 3). This result finds support from the earlier study by Obiajunwa et al [13].

\section{Difference of Mineral Concentration Among Different Seed Coat Coloured Genotypes}

Seed coat colour of sesame is commercially an important trait [15]. Morris [12] reported that people generally consume more than twice of white sesame in comparison to black sesame. A comparison of microelements among different seed coat coloured genotypes revealed that high $\mathrm{Fe}$ content (134.12 ppm) was observed in dull blackcoloured seeds, while very low $(97.27 \mathrm{ppm})$ in medium brown-coloured seeds (Table 4; Fig. 3). Zn content was estimated to be high $(65.32 \mathrm{ppm})$ in light brown-coloured seeds, while minimum (59.23 ppm) being in medium brown-coloured seeds. Cr content was high (0.90) in dull 
Table 4 Comparison of mineral content among different coloured sesame genotypes

\begin{tabular}{|c|c|c|c|c|c|c|}
\hline Seed coat colour & $\mathrm{Fe}$ & $\mathrm{Zn}$ & $\mathrm{Cu}$ & $\mathrm{Mn}$ & $\mathrm{Co}$ & $\mathrm{Cr}$ \\
\hline \multicolumn{7}{|l|}{ White } \\
\hline Mean & 108.14 & 62.84 & 20.81 & 21.95 & 42.78 & 0.44 \\
\hline Standard error & 15.23 & 3.12 & 0.704 & 1.08 & 2.50 & 0.09 \\
\hline Range & 170 & 28.94 & 8.2 & 12.7 & 27.4 & 1.09 \\
\hline \multicolumn{7}{|l|}{ Light brown } \\
\hline Mean & 123.33 & 65.32 & 19.18 & 24.7 & 32.3 & 0.43 \\
\hline Standard error & 26.89 & 2.753 & 0.75 & 1.68 & 3.59 & 0.21 \\
\hline Range & 173.4 & 17.53 & 4.9 & 11.5 & 23.2 & 1.2 \\
\hline \multicolumn{7}{|l|}{ Beige } \\
\hline Mean & 107.02 & 64.07 & 18.12 & 21.37 & 43.70 & 0.30 \\
\hline Standard error & 36.24 & 6.13 & 0.90 & 2.83 & 1.67 & 0.19 \\
\hline Range & 153.2 & 26.18 & 4 & 13 & 7.2 & 0.8 \\
\hline \multicolumn{7}{|l|}{ Medium brown } \\
\hline Mean & 97.27 & 59.23 & 18.70 & 22.69 & 34.56 & 0.40 \\
\hline Standard error & 9.22 & 2.06 & 0.53 & 0.78 & 2.16 & 0.10 \\
\hline Range & 132.7 & 33.84 & 10.9 & 9.7 & 28.8 & 1.2 \\
\hline \multicolumn{7}{|l|}{ Dark brown } \\
\hline Mean & 104.46 & 60.778 & 18.35 & 21.31 & 26.51 & 0.66 \\
\hline Standard error & 13.91 & 2.661 & 0.72 & 1.382 & 3.16 & 0.26 \\
\hline Standard deviation & 34.08 & 6.518 & 1.77 & 3.38 & 7.74 & 0.63 \\
\hline Range & 99.8 & 22.36 & 7.7 & 13.3 & 44.0 & 1.8 \\
\hline \multicolumn{7}{|l|}{ Dull black } \\
\hline Mean & 134.12 & 62.5 & 20.46 & 24.24 & 22.8 & 0.90 \\
\hline Standard error & 30.23 & 4.45 & 0.80 & 3.40 & 5.35 & 0.45 \\
\hline Range & 152.5 & 4.16 & 1.2 & 13.5 & 7.4 & 0.4 \\
\hline \multicolumn{7}{|l|}{ Bright black } \\
\hline Mean & 115.60 & 61.56 & 20.03 & 24.40 & 42.83 & 0.27 \\
\hline Standard error & 27.15 & 2.39 & 0.34 & 0.34 & 4.75 & 0.23 \\
\hline Range & 54.3 & 8.29 & 1.2 & 1.2 & 9.5 & 0.2 \\
\hline
\end{tabular}

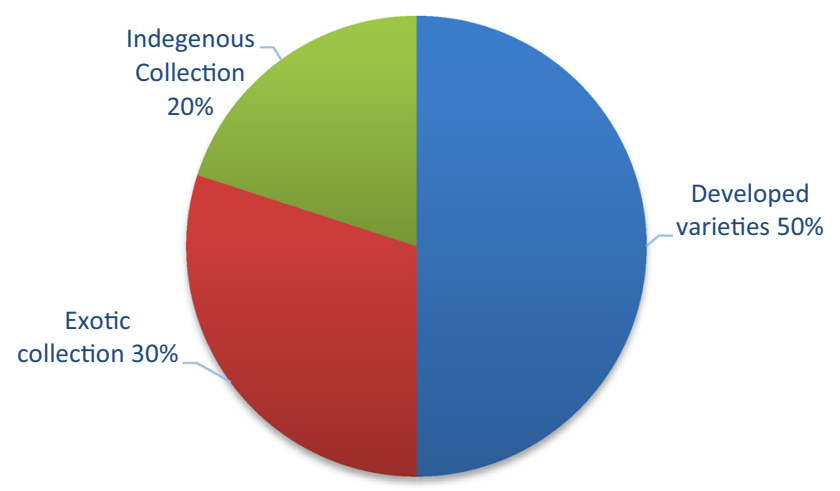

Fig. 3 Percentage of different collection of genotypes in mini core collection of sesame

black-coloured seeds, but very low $(0.27 \mathrm{ppm})$ was in bright black-coloured seeds. Co content was observed to be high (43.7 ppm) in beige, followed by bright black
(42.88 ppm) and white (42.78 ppm)-coloured seeds and lowest $(22.8 \mathrm{ppm})$ in dull black-coloured seeds. On the contrary, Mn content was high in light brown-coloured seeds, while low in beige-coloured seeds. White-seeded genotypes were associated with high $\mathrm{Cu}(20.81 \mathrm{ppm})$ content, while beige-coloured seeds showed low (18.12 ppm) Cu content (Table 4). White-seeded sesame serves as a good source of $\mathrm{Cu}$, while black-seeded sesame was found to be rich in $\mathrm{Fe}$, $\mathrm{Co}$ and $\mathrm{Mn}$ content. This result is in congruence with the study on white sesame by Sani et al [18]. Light brown-coloured seeds were good reservoir of nutrients like $\mathrm{Zn}$ and $\mathrm{Mn}$ content, whereas beigecoloured seeds contain good amount of Co. Dull blackcoloured seeds have high amount of $\mathrm{Cr}$ content. In order to improve the $\mathrm{Fe}$ and $\mathrm{Zn}$ content of seeds, black- and brownseeded genotypes may be utilized in future breeding program with other desirable coloured seed coat to obtain favourable seed coat with high nutrients. 


\section{Correlation Analysis Between Mineral Concentration and Yield Attributing Traits}

Relationships of micronutrients with seed yield and yield attributing traits have a direct influence on developing effective approaches for breeding bio-fortified crop cultivars. Correlation coefficient between yield and yield components assumes special importance in formulating the basis of selection. Correlation analysis was worked out among all the thirteen traits (Table 5). Fe was found to be positively and significantly correlated with $\mathrm{Cu}$ while a significant negative association existed with capsule length. Furthermore, Fe was highly and positively correlated with $\mathrm{Zn}$. This emphasized that any selection for higher Fe content would likely to improve $\mathrm{Zn}$ content through correlated response. $\mathrm{Zn}$ on the other hand was positively and significantly correlated with $\mathrm{Mn}$ and $\mathrm{Cu}$. $\mathrm{Cr}$ was significantly correlated with $\mathrm{Cu}$ in positive direction and with $\mathrm{Mn}$ in negative direction.
Significant negative relationship was found between numbers of seeds/capsule, seed yield/plant with cobalt content. The present findings of high positive correlation between $\mathrm{Fe}$ and $\mathrm{Zn}$ find support from the study by Morgounov et al [11] in wheat. Highly significant positive phenotypic correlations coefficient was observed between seed yield and number of capsules per plant and number of seeds per capsules. The results agreed with earlier works by Uzun et al [22]. Capsule length was positively and significantly correlated with number of seeds per capsules and 1000 seed weight. On the contrary, days to $50 \%$ flowering had significant negative correlation with seed yield per plant. Such negative effect of days to $50 \%$ flowering with seed yield was earlier reported by many researchers [25]. It is important to improve the microelements along with augmenting productivity of crops. Top $10 \%$ of mini core collection having high microelement content for $\mathrm{Fe}, \mathrm{Zn}, \mathrm{Cu}, \mathrm{Mn}$, $\mathrm{Co}$ and $\mathrm{Cr}$ has been identified (Table 6). Exotic collection genotype, EC-90, can be

Table 5 Correlation analysis for thirteen characters of 60 sesame genotypes

\begin{tabular}{|c|c|c|c|c|c|c|c|c|c|c|c|c|c|}
\hline & $\mathrm{Fe}(\mathrm{ppm})$ & $\mathrm{Zn}(\mathrm{ppm})$ & $\mathrm{Cu}(\mathrm{ppm})$ & $\mathrm{Mn}(\mathrm{ppm})$ & Co (ppm) & $\mathrm{Cr}(\mathrm{ppm})$ & DTF & DTM & $\mathrm{CL}(\mathrm{cm})$ & $\mathrm{NCP}$ & NSC & SW (g) & $\mathrm{SY}(\mathrm{g})$ \\
\hline $\mathrm{Fe}$ & 1.00 & & & & & & & & & & & & \\
\hline $\mathrm{Zn}$ & 0.15 & 1.00 & & & & & & & & & & & \\
\hline $\mathrm{Cu}$ & $0.29 *$ & $0.4 * *$ & 1.00 & & & & & & & & & & \\
\hline $\mathrm{Mn}$ & 0.23 & $0.3^{*}$ & 0.03 & 1.00 & & & & & & & & & \\
\hline $\mathrm{Co}$ & -0.21 & 0.004 & 0.12 & 0.12 & 1.00 & & & & & & & & \\
\hline $\mathrm{Cr}$ & 0.177 & 0.116 & $0.41 * *$ & $-0.29 *$ & -0.311 & 1.00 & & & & & & & \\
\hline DTF & $-0.27 *$ & 0.069 & 0.045 & -0.005 & $0.6^{* *}$ & -0.139 & 1.000 & & & & & & \\
\hline DTM & 0.219 & 0.222 & 0.147 & $0.262 *$ & 0.047 & 0.049 & 0.183 & 1.000 & & & & & \\
\hline CL & $-0.258^{*}$ & -0.115 & 0.078 & -0.250 & 0.175 & -0.055 & 0.218 & -0.084 & 1.000 & & & & \\
\hline $\mathrm{NCP}$ & 0.182 & -0.002 & 0.012 & -0.016 & 0.086 & -0.210 & 0.106 & -0.141 & -0.010 & 1.000 & & & \\
\hline NSC & -0.120 & -0.118 & -0.068 & -0.124 & $-0.275^{*}$ & 0.032 & -0.217 & 0.053 & $0.36^{* *}$ & -0.085 & 1.000 & & \\
\hline SW & -0.131 & -0.005 & 0.003 & -0.099 & $0.27 *$ & -0.100 & 0.090 & -0.096 & 0.220 & -0.119 & -0.052 & 1.000 & \\
\hline SY & 0.192 & -0.062 & -0.116 & 0.029 & $-0.303 *$ & -0.184 & $-0.431 * *$ & -0.141 & 0.111 & $0.59 * *$ & $0.37 * *$ & 0.218 & 1.000 \\
\hline
\end{tabular}

* Significant at $5 \%$ level of significance; ** significant at $1 \%$ level of significance; days to $50 \%$ flowering (DTF), days to maturity (DTM), capsule length (CL), number of capsules/plant (NCP), number of seeds/capsule (NSC), 1000 seed weight (SW) and seed yield/plant (SY)

Table 6 List of top $10 \%$ of mini core collection having high microelement content for $\mathrm{Fe}, \mathrm{Zn}, \mathrm{Cu}, \mathrm{Mn}$, $\mathrm{Co}$ and $\mathrm{Cr}$

\begin{tabular}{llllll}
$\begin{array}{l}\text { Genotypes for } \\
\text { Fe content }\end{array}$ & $\begin{array}{l}\text { Genotypes for } \\
\text { Zn content }\end{array}$ & $\begin{array}{l}\text { Genotypes for } \\
\text { Cu content }\end{array}$ & $\begin{array}{l}\text { Genotypes for } \\
\text { Mn content }\end{array}$ & $\begin{array}{l}\text { Genotypes for } \\
\text { Co content }\end{array}$ & $\begin{array}{l}\text { Genotypes for } \\
\text { Cr content }\end{array}$ \\
\hline NIC-8316 & TKG-22 & OSC-207 & TKG-22 & RT-348 & EC-79 \\
EC-87 & AMRIT & V15 & UMA & GUJARAT TIL-2 & TILLOTAMA \\
EC-90 & IC-41 & DSS-09 & IC-54 & BC-91 \\
IC-42 & IC-59 & IC-41 & EC-90 & DSS-09 & EC-108 \\
IC-59 & EC-107 & EC-107 & EC-87 & TMV-6 & IC-49 \\
EC-91 & & IC-59 & & SAHEB & \\
EC-67 & & & & \\
EC-107 & & & & \\
IC-54 & & & & \\
V10 & & & & \\
\hline
\end{tabular}


incorporated in nutrient breeding program as it possessed more than six times iron content than the popular highyielding variety 'Savitri'. Similarly, EC-107 and IC-59 have high $\mathrm{Fe}, \mathrm{Zn}$, and $\mathrm{Cu}$ content in seeds and can be utilized as parent in breeding program for improvement of microelements (Table 6). It suggested that light brown-seeded sesame could be the better dietary resource for $\mathrm{Zn}$ deficiency. Both $\mathrm{Fe}$ and $\mathrm{Zn}$ were found to be positively associated, and simply by conventional breeding program, it is possible to improve $\mathrm{Fe}$ and $\mathrm{Zn}$ content in seeds. Moreover, among the morphological traits, seed yield was correlated positively with number of capsules/plant and number of seeds/capsule. Thus, it is possible to increase seed yield further by augmenting these two traits. The significant correlation between microelement content and morphological traits can help in the indirect selection for simultaneous improvement of both mineral contents and yield traits. Interestingly, $\mathrm{Fe}$ and $\mathrm{Zn}$ content were not correlated to either of the traits, and thus, restructuring of plant type with high yield with higher content of Fe and $\mathrm{Zn}$ is achievable targets through breeding approach like transfer of gene for high $\mathrm{Fe}$ and $\mathrm{Zn}$ content to high-yielding genotypes.

\section{Conclusions}

In present study, most of the indigenous collections have been found to be rich in mineral contents and hence can be used as breeding material for further research to understand the genetic mechanisms responsible for mineral absorption and accumulation. It was also evident from the study that seed coat colour of the seeds may differentiate the genotypes in relation to their microelement concentrations. Genotypes like EC-107 and IC-59 having higher Fe, Zn, and $\mathrm{Cu}$ have great potential to be utilized as parent in breeding programs. Of the different coloured seeds studied, the concentration of $\mathrm{Fe}$ and $\mathrm{Mn}$ in black-seeded genotypes was significantly higher than those in white seeded.

\section{References}

1. Akpapunam MA, Sefa-Dedeh S (1995) Traditional lactic acid fermentation, malt addition, and quality development in maizecowpea weaning blends. Food Nutr Bull 16:75-80

2. Allard RW (1960) Principal of plant breeding. Wiley, New York

3. Alobo A (2001) Effect of sesame seed flour on millet biscuit characteristics. Plant Foods Hum Nutr 56:195. doi:10.1023/A: 1011168724195

4. Alyemeni MN, Basahy AY, Sher H (2011) Physico-chemical analysis and mineral composition of some sesame seeds (Sesamum indicum L.) grown in the Gizan area of Saudi Arabia. J Med Plants Res 5:270-274
5. Burton GW (1952) Quantitative inheritance in Grasses. In: Proceedings of the sixth international grassland congress, pp 227-283

6. Cao L, Geng W, Wei YS (2012) Determination of 18 mineral elements of (Sesamum indicum L.) by microwave digestion-ICPOES. Appl Chem Ind 5:910-913

7. Dar AA, Verma NK, Arumugam N (2015) An updated method for isolation, purification and characterization of clinically important antioxidant lignans-Sesamin and sesamolin, from sesame oil. Ind Crops Prod 64:201-208

8. Graham RD, Welch RM (1996) Breeding for staple food crops with high micronutrient density. International Food Policy Research Institute, Washington

9. Kanatti A, Rai KN, Radhika K, Govindaraj M, Sahrawat KL, Rao AS (2014) Grain iron and zinc density in pearl millet: combining ability, heterosis and association with grain yield and grain size. Springer Plus 3:763

10. Kotecha PV (2011) Nutritional anemia in young children with focus on Asia and India. Indian J Community Med 36:8-16

11. Morgounov A, Gomez-Becerra HG, Abugalieva A, Dzhunusova M, Yessimbekova M, Miminjanov H, Zelenskiy Y, Ozturk L, Cakmak I (2007) Iron and zinc grain density in common wheat grown in Central Asia. Euphytica 155:193-203

12. Morris JB (2002) Food, industrial, nutraceutical, and pharmaceutical uses of sesame genetic resources. Trends in new crops and new uses. ASHS press, Alexandria VA, pp 153-156

13. Obiajunwa EI, Adebiyi FM, Omode PE (2005) Determination of essential minerals and trace elements in Nigerian sesame seeds, using TXRF technique. Pak J Nutr 4:3-395

14. Özcan M (2003) Antioxidant activities of rosemary, sage, and sumac extracts and their combinations on stability of natural peanut oil. J Med Food 6:267-270

15. Pandey SK, Das A, Dasgupta T (2013) Genetics of seed coat colour in sesame (Sesamum indicum L.). Afr J Biotechnol 12:6061-6066

16. Pandey SK, Das A, Rai P, Dasgupta T (2015) Morphological and genetic diversity assessment of sesame (Sesamum indicum L.) accessions differing in origin. Physiol Mol Biol Plants 21(4):519-529. doi:10.1007/s12298-015-0322-2

17. SPSS Inc. Released (2008) SPSS Statistics for Windows, Version 17.0. Chicago

18. Sani I, Sule FA, Warra AA, Bello F, Fakai IM, Abdulhamid A (2013) Phytochemicals and mineral composition of white Sesamum indicum L. Seed Oil. Int J Trad Nat Med 2(118):130

19. Sarwar G, Haq MA, Chaudhry MB, Rabbani I (2007) Evaluation of early and high yielding mutants of sesame (Sesamum indicum L.) for different genetic parameters. J Agric Res 45:125-133

20. Soetan KO, Olaiya CO, Oyewole OE (2010) The importance of mineral elements for humans, domestic animals and plants: a review. Afr J Food Sci 4:200-222

21. Upadhyaya H, Ortiz R (2001) A mini core subset for capturing diversity and promoting utilization of chickpea genetic resources in crop improvement. Theor Appl Genet 102:1292. doi: 10.1007/s00122-001-0556-y

22. Uzun B, Engin Y, Furat S (2013) Genetic advance, heritability and inheritance in determinate growth habit of sesame. Aust $\mathbf{J}$ Crop Sci 7:978-983

23. White PJ, Broadley MR (2005) Biofortifying crops with essential mineral elements. Trends Plant Sci 10:586-593

24. World Health Organization (2002) The world health report: reducing risks, promoting healthy life. World health Organisation Press, Geneva

25. Yol E, Karaman E, Furat S, Uzun B (2010) Assessment of selection criteria in sesame by using correlation coefficients, path and factor analyses. Aus J Crop Sci 4:598-602 